\title{
Registration of Electronic Integrated Mortgage Rights of the Written Certificate of Land Rights in the Name of the Debtor
}

\author{
Mahendra Wardhana* \\ Department of Law, Faculty of Social \\ Sciences and Law \\ Universitas Negeri Surabaya \\ Surabaya, Indonesia \\ mahendrawardhana@unesa.ac.id
}

\author{
Dita Perwitasari \\ Department of Law, Faculty of Social \\ Sciences and Law \\ Universitas Negeri Surabaya \\ Surabaya, Indonesia \\ ditaperwitasari@unesa.ac.id
}

\author{
Tamsil \\ Department of Law, Faculty of Social \\ Sciences and Law \\ Universitas Negeri Surabaya \\ Surabaya, Indonesia \\ tamsil@unesa.ac.id
}

\author{
Indri Fogar Susilowati \\ Department of Law, Faculty of Social \\ Sciences and Law \\ Universitas Negeri Surabaya \\ Surabaya, Indonesia \\ indrifogar@unesa.ac.id
}

\begin{abstract}
HT-el services that meet the principles of openness, timeliness, speed, convenience and affordability that are the ideals of PermenATR / KBPN 9/2019 are a little "tarnished" by the existence of an article that does not accommodate these conveniences, namely in Article 9 paragraph 5 Permen ATR / KBPN 9/2019 which states that "Requirements in the form of a Certificate of Land Rights or Ownership Rights in a Flats Unit must be in the name of the debtor." What if the certificate is in the name of the guarantor or another party, whose name is not the debtor. Is the certificate of land rights then can not be encumbered with mortgage rights?. The purpose of this research article is to provide understanding for the people who are of course the target for the use or implementation of this HT-el. The research method in writing this article is a normative juridical approach where legal research is carried out by examining library materials or secondary data as a basis for research by searching for the regulations and literature relating to the problem under study. The results of this study are that changes must be made to PermenAg No. 9/2019 especially in Article 9 paragraph 5 which states that "Requirements in the form of a Certificate of Land Rights or Ownership Rights in a Flats Unit must be in the name of the debtor" to "Requirements in the form of Certificates of Land Rights or Ownership Rights in the Flats must be in the name of the giver mortgage right".
\end{abstract}

Keywords: HT-el, UUHT, Debtor

\section{INTRODUCTION}

Banks have two important roles in economic and business life. The first role is as a fund-raising institution, which collects funds owned by the community and then deposited in banks in the form of savings or products owned by other banks. The second role is as an institution channeling funds, namely channeling funds belonging to the community or the bank's capital to those who need funds or capital in the form of credit.

Credit comes from the Roman "credere" which means to believe. The basis of credit is trust. The party that gives the credit (the creditor) believes that the recipient of the credit (the debtor) will be able to fulfill everything that has been promised, both regarding the period, as well as achievements and contrasts. Basic conditions like this are required by the Bank because the funds in the bank are mostly owned by third parties, for this reason, it is necessary for the Bank's discretion in using these funds, including determining credit-granting [1]. Banks as financial institutions in implementing the precautionary principle apply the formula $5 \mathrm{C}$ (Five C's Principle) which is a formula that is adhered to by banks in analyzing credit applications for later channeling credit. Regarding the formula $5 \mathrm{C}$ can be described as follows:[2]

\section{Character}

That prospective debtor customers have good character, morals, and personal qualities. This character assessment is carried out to determine the level of honesty, integrity, and willingness of prospective borrowers to meet their obligations and conduct business. This information can be obtained by the bank through curriculum vitae, business history, and information from similar businesses. 


\section{Capacity}

What is meant by capacity, in this case, is the ability of prospective borrowers to manage their business activities and be able to see prospective future, so that their business will run well and provide benefits that guarantee that it can pay off its credit debt in a specified amount and period.

\section{Capital}

In this case the bank must first research the capital owned by the credit applicant. The investigation is not solely based on the size of the capital but rather is focused on how the distribution of capital is placed by the entrepreneur so that all existing sources can run effectively.

\section{Collateral}

It is a guarantee to grant credit which is a means of safety (backing up) of the risks that may occur on the default of debtor customers in the future, for example, bad loans occur. This guarantee is expected to be able to pay off the remaining credit debt, both the principal debt and the interest.

\section{Condition of Economy.}

In granting credit by banks, the general economic conditions and business sector conditions of credit applicants need to get the attention of banks to minimize the risks that might occur caused by these economic conditions.

One of the most important principles in lending is collateral or collateral, which is an element that serves to minimize the risk in channeling credit because collateral is a matter of providing a "sense of security" for creditors if a debtor cannot pay credit installments to creditors following what was promised.

According to Article 1131 of the Civil Code, hereinafter referred to as the Civil Code, that "All debtors' assets, both in the form of movable objects and fixed objects, both existing and new will be in the future, become guarantees for all the debt agreement "[3]. According to the provisions of Article 1132 of the Civil Code, the assets of the Debtor are jointly collateral for all creditors who give debt to the debtor concerned. The proceeds from the sale of the objects that become the debtor's wealth are divided among all creditors in a balanced or proportional manner according to the ratio of the number of their respective receivables, but among the creditors can take precedence over other creditors if there are valid reasons to take precedence, namely the reasons specified by law.

In Article 1133 of the Civil Code it is determined that the right to take precedence for a particular creditor against other creditors arises from the Privileges, Pledges, and Mortgages. The order of the rights to take precedence arising from the three rights that the Liens and Mortgages have a higher position than the privileges except in matters that are determined by the Act otherwise. In credit practice, asking for or providing a guarantee of immovable property or material security in the form of land is the most popular guarantee, this is a reasonable thing because economically, land prices from time to time are highly valued.

The binding of land as collateral in a credit agreement is regulated by Law Number 4 of 1996 concerning Mortgage Rights and Land Related Objects (hereinafter referred to as UUHT) which is a substitute for Hypotheek (hereinafter referred to as a Mortgage) as regulated in book II of the Civil Code as far as land and
Credietverband are regulated in Staatsblad 1937-190, which is based on Article 57 of Law Number 5 of 1960 concerning Basic Regulations on Agrarian Principles (hereinafter referred to as UUPA). Underwriting Right along with objects related to land, hereinafter referred to as Underwriting Right, is a guaranteed right which is imposed on land rights as referred to in the UUPA, here or not, along with other objects which form an integral part of the land, to settle debts. certain, which gives priority to certain creditors to other creditors [4].

That objects (land) that will be used as collateral for a debt-burdened with Underwriting Rights, the object concerned must fulfill the following conditions:: [5]

1. because debt guaranteed in the form of money;

2. Including the rights registered in the public register, because they must meet the requirements of publicity;

3. Has transferable nature, because if the debtor fails to promise, the object which is used as collateral will be able to be sold in public; and

4. Requires appointment by law.

In addition to these requirements, in point 3 the UUHT explanation explains that based on this fact, it is necessary to immediately enact a law concerning strong land rights institutions with the following characteristics:

a. give priority or position to the holder;

b. always follows the object guaranteed in the hand of whoever the object is;

c. fulfill the principle of specialty and publicity so that it can bind a third party and provide legal certainty to the parties concerned;

d. easy and certain implementation of the execution.

In connection with the conditions referred to above, that Article 4 of the UUHT has determined the type of land rights that can be encumbered with Mortgage Rights, namely:

1. Land rights that can be encumbered with Underwriting Rights are:

a. Right of ownership

b. Cultivation Rights

c. Building rights

2. In addition to the land rights as referred to in paragraph (1), the Right to Use the State Land which according to the provisions in force must be registered and according to its transferable nature can also be encumbered with a Mortgage Right.

The current era of globalization has led to a development in the needs of society, not least the ownership of land or land either for settlements or for other needs. Especially since the stipulation of Government Regulation Number 82 of 2012 concerning the Implementation of Electronic Transactions and Systems. This is what demands the government to be able to update the system and increase data management related to land affairs, the aim of which is to achieve orderly [6]. Improvement of the orderly system of land administration as well as transactions and product services related to land data collection carried out by the Ministry of Agrarian Land Management / National Land Agency (Ministry of ATR / BPN) as the party responsible for data collection and management of the land system [7].

The Ministry of ATR / BPN has issued Minister of Agrarian Regulation and Spatial Planning Head of National Land Agency Number 9 of 2019 regarding Electronic 
Integrated Mortgage Rights Services since enacted on June 21, 2019 (Permen ATR / KBPN 9/2019). The ministerial regulation is a continuation of the previously issued PermenATR / KBPN, namely Regulation of the Minister of Agrarian Affairs and Spatial Planning / Head of National Land Agency Number 3 of 2019 concerning Use of Electronic Systems and Regulation of the Minister of Agrarian Affairs and Spatial Planning / Head of BPN number 7 of 2019 Concerning Changes Certificate Form. Therefore, the issuance of two new regulations within the Ministry of Agrarian Affairs and Spatial Planning as a breakthrough utilizing the development of existing technology at this time is expected to accommodate the interests and needs of the community concerning services by registering electronic mortgage rights (hereinafter referred to as HT-el). Because one of the objectives of this HT-el is to facilitate and provide the best service for the community. Following the directions of the legislation.

This is by the provisions in weighing PermenATR / KBPN 9/2019 which states that to improve the services of mortgage rights that meet the principles of openness, timeliness, speed, convenience, and affordability in the framework of public services, as well as to adjust the development of law, technology, and community needs, need to utilize information technology so that the procedure for mortgage rights can be integrated electronically so that it becomes more effective and efficient;

HT-el services that fulfill the principles of openness, timeliness, speed, convenience and affordability which are the ideals of PermenATR / KBPN 9/2019 are a little "tarnished" by the existence of an article that does not accommodate these conveniences, namely in Article 9 paragraph 5 PermenATR / KBPN 9/2019 which states that "Requirements in the form of a Certificate of Land Rights or Ownership Rights in a Flats Unit must be in the name of the debtor."

The existence of Article 9 paragraph 5 of PermenATR / KBPN 9/2019 becomes a problem when the certificate used as collateral is not written in the debtor's name. What if the certificate is in the name of the guarantor or another party, whose name is not the debtor. Is the certificate of land rights then can not be encumbered with mortgage rights?

Based on the problems that have been presented above, the following is the formulation of the problems related to this writing (1) how is HT-el's registration of a land rights certificate not written in the debtor's name?

\section{RESEARCH METHOD}

Legal research is the process of finding the rule of law, legal principles, and legal doctrines to obtain solutions to legal problems [8]. This is consistent with the prescriptive character, legal research carried out to produce new arguments, theories, or concepts as a recipe for solving problems. If a descriptive study of the answers is expected to be true or false, the response expected in legal research is true, correct, incorrect, or false. thus it can be said that the results obtained in legal studies already contain values.

Based on the above definition, normative research seeks to study and explore and find answers about what should exist in each problem [9]. In contrast to descriptive research that only describes what is right, and what is wrong from any problem, and all the factors that influence it.

The approach used is the statute approach and conceptual approach. The Statute Approach is examining all actions and regulations relevant to legal matters. The conceptual approach is examining the ideas and doctrines of experts developed in jurisprudence. Through learning ideas and doctrines in law, researchers will find ideas that build legal ideas, legal concepts, and legal principles that are relevant to the problem at hand. An understanding of understanding and doctrine is the basis for researchers in building legal arguments in solving the problem at hand.

\section{RESULTS AND DISCUSSION}

The stipulation of PermenATR / KBPN 9/2019 in the era of globalization is to accommodate the development of law, technology, and community needs so that information technology is expected to increase the effectiveness and efficiency of procedures that were originally carried out manually into services that are electronically integrated mortgage rights. The Ministerial Regulation is expected to be able to improve the service of mortgage rights that meet the principles of openness, timeliness, speed, convenience, and affordability in the framework of public services.

Under PermenATR / KBPN 9/2019 that the service of mortgage rights is carried out electronically through the HT-el System organized by the Land Office gradually adjusting to the readiness of supporting data, where the HTel system is a certified system from the competent authority. Types of services that can be submitted through the HT-el system include:

a. Registration of mortgage rights;

b. Transfer of mortgage rights;

c. Change in creditor names;

d. Abolition of mortgage.

To be able to use the HT-el service, it must meet the requirements as a subject of HT-el system service users as referred to in Article 7 paragraph (1) PermenATR / KBPN 9/2019 which includes:

a. individuals / legal entities as creditors as stipulated in the laws and regulations governing Mortgage Rights; and

b. The State Civil Apparatus of the Ministry in charge of serving Mortgage Rights.

The individual or legal entity must be a Registered User of the HT-el System, which is a service user who qualifies as an HT-el System user with rights and obligations regulated by the Ministry of Agrarian and Spatial Planning. The requirements for registering to become a registered user in the HT-el system include:

a. has an electronic domicile;

b. Certificate of Registered at the Financial Services Authority;

c. a statement of fulfillment of the requirements and criteria as well as the approval of the provisions as Registered User; and

d. other conditions determined by the Ministry.

Upon the registration, the Ministry of Agrarian Affairs and Spatial Planning verifies the registration and has the right to reject the said registration, and the registered user has the right to use the HT-el System with all its supporting features and is obliged to comply with the terms and conditions stipulated in the HT-el System. 
According to Article 9 PermenATR / KBPN 9/2019 requirements for service applications for Underwriting Rights by the provisions of the legislation as well as a Declaration regarding the accountability and validity of the Electronic Document data submitted. However, it becomes a problem when the conditions as stated in Article 9 paragraph 5 PermenATR / KBPN 9/2019 requires that the Certificate of Land Rights or Ownership Rights in Flats is to be in the debtor's name.

There is not a single article in the UUHT, Regulation of the Minister of Agrarian / Head of National Land Agency Number 5 of 1996 concerning registration of mortgage rights, and Government Regulation Number 24 of 1997 concerning Land Registration and Regulation of the Minister of Agrarian / Head of National Land Agency Number 3 of 1997 concerning Regulation Implementing Government Regulation Number 24 of 1997 concerning Land Registration which states that certificates that are registered under the mortgage must be written in the debtor's name.

To answer a multi-interpreted rule in Article 9 paragraph 5 PermenATR / KBPN 9/2019 which states that "Requirements in the form of a Certificate of Land Rights or Ownership Rights in a Flats must be in the name of the debtor.", It is necessary to first understand what is the definition from the Debtor ". Both UUHT and PermenATR / KBPN 9/2019 define a Debtor as a party that owes a certain debt-to-debt relationship.

Whereas debts (credit) in the Law of the Republic of Indonesia Number 10 of 1998 concerning Amendment to Law Number 7 of 1992 concerning Banking is the provision of money or bills that can be equalized, based on an agreement or loan agreement between the bank and other parties that require the borrower to repay the debt after a certain time with the provision of interest;

The party that owes using movable or immovable property as collateral to both bank and non-bank financial institutions or to non-financial institutions, which due to several debt loans creates a legal relationship between debt and debt between the debtor and the creditor. In this case if the land is used as collateral by the debtor, then it must be followed by granting mortgage rights to the creditor

The promulgation of the promise to provide mortgage rights in the debit and credit agreement is regulated in Article 10 paragraph (1) of the UUHT which reads as follows:

"The granting of Mortgage Rights is preceded by a promise to provide the Mortgage Right as a guarantee for paying off certain debts, which are outlined in and are an inseparable part of the related debt agreements or other agreements that cause these debts."

The emergence of mortgage rights is only possible if it has been previously agreed in a debit-credit agreement (credit) which is the basis for granting debt (credit) guaranteed by the Mortgage that the Mortgage will be given to the creditor. While the granting of the Underwriting Right itself will be done by making a separate agreement by the Land Deed Making Officer (PPAT).

The mortgage agreement is not a stand-alone agreement. Its existence is due to another agreement, which is called the master agreement. The master agreement for the mortgage agreement is a debt and debt agreement that creates a guaranteed debt.

Here we see the nature of the accession of a collateral engagement, because it is dedicated to a certain guaranteed principal contract, which in principle can be any engagement obligation, but generally in the form of debt or credit agreements. The main commitment is an independent agreement, independent of the guarantee agreement [10]. Article 8 of the General Elucidation of the UUHT states that:

"Because the Underwriting Right is by its nature a follow-up or access to a certain receivable, which is based on a debt-receivable agreement or other agreement, then the existence are determined by the existence of receivables that are guaranteed repayment."

That the security rights as an access agreement are based on Article 10 paragraph (1) and Article 18 paragraph (1) UUHT, which is because:

(a) Article 10 paragraph (1) of the UUHT determines that an agreement to provide mortgage rights is an inseparable part of the debt agreement concerned.

(b) Article 18 paragraph (1) letter a determines the write off right because the write off of the debt guaranteed by the mortgage.

So by the nature of the access to an agreement, the existence, transfer, and removal of the guarantee agreement, depends on the underlying agreement (Article 16 jo Article 18 UUHT). If the underlying agreement switches, the collateral engagement also moves, if the principal agreement is deleted, the engagement will also be deleted. A new guarantee is born or has work power if the engagement is born.

Like every other agreement, in the agreement to grant the mortgage there are 2 (two) parties that face each other, namely the creditor, which after the granting of the mortgage will be called the mortgage right and the grantor, which can be the debtor himself or a third party, so they will be called the debtor giving the mortgage right or the third party giving the mortgage right [10].

We can see the definition of mortgage rights and mortgage rights holders in Article 8 (1) and Article 9 of the UUHT which states that:

Article 8 (1) UUHT Giver of Underwriting Right is an individual or legal entity that has the authority to carry out legal actions against the object of the Underwriting Right concerned.

Article 9 UUHT Underwriting Rights Holders are individuals or legal entities that are domiciled.

Regarding the polemic in Article 9 paragraph 5 PermenATR / KBPN 9/2019 which states that "Requirements in the form of a Certificate of Land Rights or Ownership Rights in a Flats must be in the name of the debtor.", Then in this case we will focus more on the discussion of the giver of rights the dependents as referred to in Article 8 paragraph (1) of the UUHT.

Therefore, because the object of mortgage is a right to land that can be in the form of ownership rights, land use rights, and building use rights, in line with the provisions of Article 8 paragraph (1) of the UUHT, those who can become mortgage rights are individuals or legal entities that are can have Ownership Rights, Business Use Rights, and Building Use Rights as regulated in Article 25, Article 33 and Article 39 of the UUPA.

The mention of "natural persons" or "legal entities" is excessive, because in granting mortgages the object guaranteed in principle is a land, and according to the UUPA, those who can have land rights are both individuals and legal entities (vide Article 21, Article 30, Article 36 and Article 45 of the UUPA). For each land rights, of course the giver of the mortgage right as the owner of the land rights 
must fulfill the conditions of ownership of the land, as determined individually in the law [10].

Furthermore, the requirement that the mortgage right must have the authority to take legal action on the object guaranteed is incomplete, because the name of the legal action can include both the act of management (beheersdaden) and the act of ownership (beschikkingsdaden), whereas the act of guarantee is an act of ownership (beholding) not handling). So it is better to say, that the condition is that the mortgage right must have the authority to buy the collateral [10].

If the provider of a mortgage is a limited liability company, the implementation must take into account the provisions of Law Number 40 of 2007 concerning Limited Liability Companies (hereinafter referred to as UUPT). According to the provisions of the Company Law, the Board of Directors is required to seek approval from the General Meeting of Shareholders (GMS) to transfer or guarantee the debt in whole or in part of the company's assets.

The authority for the act of ownership is only required at the time of registration of mortgage (Article 8 paragraph (2) UUHT). So it is possible, that the person who promised the mortgage right at the time the object that was pledged was not his property as long as later at the time of registration of the mortgage, the collateral object had become the property of the mortgage right. This is an attempt by lawmakers to accommodate practical needs, where people can pledge parcels, which will still be purchased with credit money from creditors. For those who will receive mortgage rights, they must pay attention to the provisions of Article 8 paragraph (2) of the UUHT which stipulates that the authority to carry out legal actions against the object of mortgage as referred to in article 8 paragraph (1) of the UUHT above must exist (must already exist and still exist there are) to the mortgage right at the time the registration of the mortgage rights is carried out.

Why does the UUHT determine that the authority must exist at the time the registration of the mortgage is carried out? Since the existance of the mortgage is at the time of registration of the mortgage, the authority to take legal action against the object of the mortgage right must be present (already exists and still exists) on the mortgage right at the time of drafting the land rights document, According to the explanation of article 8 paragraph (2) UUHT, for that reason, the validity of the authority must be proven at the time the registration of the relevant mortgage rights is registered [3]

According to Article 13 paragraph (1) UUHT must be registered at the land office. In Article 13 paragraph (2) and paragraph (3) of the UUHT it is explained how the registration of the mortgage is done. Furthermore, Article 14 paragraph (1) of the UUHT determines that as proof of Mortgage Rights. The Land Office issues a mortgage certificate per the applicable laws and regulations. After the mortgage certificate is issued by the land office and the land rights certificate is affixed with a note the burden of the mortgage is given to the mortgage right holder.

The technical implementation of the registration of mortgage rights is regulated by the Regulation of the Minister of Agrarian / Head of the National Land Agency Number 5 of 1996 concerning registration of mortgage rights and then elaborated further in Government Regulation Number 24 of 1997 concerning Land Registration and Regulation of the Minister of Agrarian / Head of the National Land Agency Number 3 Year 1997. The purpose of the issuance of this regulation is to regulate the procedure for registration of mortgage and requirements according to the provisions of Article 10, Article 13 and Article 14 of the UUHT.

One embodiment of granting legal certainty, as mentioned in the weighing section at the opening of the UUHT, is the obligation to register mortgages as an embodiment of the principle of publicity, even though the same principle has also been applied to mortgages. In this case there is a difference between mortgage registration and mortgage rights. The difference is that in the UUHT the deadline for implementing the registration is set, which is no later than 7 (seven) days after the signing of the deed of granting mortgage rights (APHT). The registration is a registration in the land title mortgage and in the register of land rights concerned, which is available at the local land office.

Immovable objects or land pledged as objects of mortgage rights in APHT are property rights, building rights and business rights here or not, including objects attached to them under the UUHT title itself and all other objects according to the horizontal separation principle adopted by agrarian law we are indeed a separate part.

The collateral items can belong to the debtor itself or third parties (article 4 paragraph (4) and paragraph (5) of the UUHT. If the guarantor is the debtor himself, then the relevant party is called the debtor giving the mortgage, while if the grantor the guarantee is a third party, so the person concerned is called a third party giving the mortgage right [10].

Article 4 paragraph (4) of the UUHT states that Mortgage Rights can also be imposed on land rights including buildings, plants, and works that already exist or will exist which are one unit with the land, and which belongs to the holder of the land rights whose land is charged expressly stated in the Deed of Granting the Underwriting Rights concerned.

Article 4 paragraph (5) of the UUHT states that if buildings, plants, and works as referred to in paragraph (4) are not owned by holders of land rights, the imposition of Mortgage Rights on such objects can only be done by signing along with the Deed of Granting Rights The dependents concerned by their owners or who have been authorized by it by authentic deeds.

Back to the rules in the UUHT, Regulation of the Minister of Agriculture / Head of the National Land Agency Number 5 of 1996 concerning registration of mortgage rights, and Government Regulation Number 24 of 1997 concerning Land Registration and Regulation of the Minister of Agrarian / Head of the National Land Agency Number 3 of 1997 concerning Implementing Regulation Government Regulation Number 24 of 1997 concerning Land Registration states that certificates that are registered under the mortgage must be written in the debtor's name. Therefore based on the theories and explanations stated above, it is not true Article 9 paragraph 5 PermenATR / KBPN 9/2019 which states that "Requirements in the form of a Certificate of Land Rights or Ownership Rights in a Flats Unit must be in the name of the debtor." This article does not provide a way for the creditor who is not or has not become a debtor so that the mortgage can be registered through HT-el.

What about the mortgage rights provider who is not a debtor but as a guarantor, so that the certificate will be guaranteed? How about the mortgage rights provider who is 
the parent of the debtor whose name is listed in the certificate or the person who promised the mortgage rights when the object guaranteed is not his property as long as at the time of registration of the mortgage, the security object has become the property of the mortgage right (buyer house by credit) or other possibilities that do not accommodate an unwritten certificate in the name of the debtor.

Matters such as those mentioned above are obstacles to HT-el registration. As already stated, PermenATR / KBPN No. 9/2019 has indeed been published and valid since promulgation, but in its implementation PermenAg No. 9/2019 concerning HT-el is still ongoing or is done depending on the readiness of each land office in implementing this electronic system to provide services to the community.

PermenATR / KBPN No. 9/2019 can differentiate between debtors and dependents as well as UUHT. In APHT, which has an accessoir nature, there are two parties, namely the creditor, who after the granting of the mortgage will be called the mortgage right and the grantor is the debtor himself or a third party, so they will be called the debtor or the third party grantor of the mortgage.

At the moment the registration of mortgage rights with the name of the debtor is different from the name listed in the certificate which is a guarantee, the APHT that will be registered cannot be registered online or online system must be registered manually, re-registration at the local land office.

Following the ideals of the stipulation of PermenATR / KBPN No. 9/2019 so that the mortgage service procedure can be integrated electronically so that it becomes more effective and efficient, then not only collateral objects written on behalf of debtors can be registered but also not written on behalf of debtors. Therefore, the collateral objects that can be registered through HT-el are all collateral objects granted by the Underwriter who are individuals or legal entities that can have Ownership Rights, Business Permit and Building Use Rights or Ownership Rights over Flats.

Therefore, for HT-el registration to be carried out properly for all collateral objects in Indonesia, changes must be made to PermenATR / KBPN No. 9/2019 with the Regulation of the Minister of Agrarian Affairs and Spatial Planning / Head of the National Land Agency, particularly in Article 9 paragraph 5 which states that "Requirements in the form of Land Rights Certificates or Ownership Rights in Flats must be in the name of debtors" to "Requirements in the form of Land Rights Certificates Land or Ownership Rights in the Flats must be in the name of the giver of mortgages ".

\section{CONCLUSION}

Based on the discussion above it can be concluded that,Permen ATR / KBPN No. 9/2019 should be able to differentiate between debtors and dependents as is the case with the UUHT. In APHT, which has an accessoir nature, there are two parties, namely the creditor, who after the granting of the mortgage will be called the mortgage right and the grantor is the debtor himself or a third party, so they will be called the debtor which gives the mortgage right or the third party gives the mortgage right.

At the moment the registration of mortgage rights with the name of the debtor is different from the name listed in the certificate which is a guarantee, the APHT that will be registered cannot be registered online or online system must be registered manually, re-registration at the local land office.

Under the ideals of the stipulation of PermenATR / KBPN No. 9/2019 so that the procedure for mortgage service can be integrated electronically so that it becomes more effective and efficient, then not only collateral objects are written on behalf of debtors can be registered but also not written on behalf of debtors.

Recommendation for this issues is collateral objects that can be registered through HT-el should be all collateral objects granted by the Underwriting Right provider who are individuals or legal entities that can have Ownership Rights, Business Rights, and Building Use Rights or ownership rights over the apartment units.

Therefore, for HT-el registration to be carried out properly for all collateral objects in Indonesia, changes must be made to PermenATR / KBPN No. 9/2019 with the Regulation of the Minister of Agrarian Affairs and Spatial Planning / Head of the National Land Agency, particularly in Article 9 paragraph 5 which states that "Requirements in the form of Land Rights Certificates or Ownership Rights in Flats must be in the name of debtors" to "Requirements in the form of Land Rights Certificates Land or Ownership Rights in the Flats must be in the name of the giver of mortgages ".

\section{REFERENCES}

[1] Muhammad Djumhana, Hukum Perbankan di Indonesia. Bandung: PT. Citra Aditya Bakti, 1993.

[2] Hermansyah, Hukum Perbankan Nasional Indonesia. Jakarta: Kencana prenada media group, 2012.

[3] R. Sjahdeini, Hak Tanggungan Asas-Asas, Ketentuan-Ketentuan Pokok dan Masalah Yang Dihadapi oleh Perbankan Penerbit. Bandung: Alumni, 1996.

[4] H. Adjie, Hak Tanggungan Sebagai Lembaga Jaminan Atas Tanah. Bandung: CV. Mandar Maju, 2018.

[5] Boedi Harsono dan Sudaryanto Wirjodarsono, Konsepsi Pemikiran Tentang Undang-Undang Hak Tanggungan, Makalah Seminar Nasional "Kesiapan dan Persiapan Dalam Rangka Pelaksanaan Undang-Undang Hak Tanggungan." Bandung: Fakltas Hukum Padjajajaran, 1996.

[6] A. A. Rizqi, "PERLINDUNGAN HUKUM PEMILIK SERTIPIKAT HAK ATAS TANAH DALAM HAL TERJADI KESALAHAN DATA PENERBITANNYA (Studi Kasus Di Kantor Pertanahan Kota Semarang)," NOTARIUS, 2018.

[7] K. S. Antoro, "Jurnal Agraria dan Pertanahan," bhumi J. Agrar. dan Pertanah., 2016.

[8] "PENYELESAIAN SENGKETA PERBEDAAN DATA FISIK DALAM SERTIPIKAT DENGAN HASIL UKUR TERHADAP GANTI RUGI KEPADA MASYARAKAT DI KELURAHAN PADANGSARI KECAMATAN BANYUMANIK KOTA SEMARANG (Dalam Rangka Pengadaan Tanah Untuk Jalan Tol Semarang-Solo)," 
NOTARIUS, 2009.

[9] J. Ibrahim, "Teori dan Metode Penelitian Hukum Normatif," Bayu Media, Malang, 2006.

[10] J.Satrio, "Hukum Jaminan Hak Jaminan Kebendaan," Bandung: PT. Citra Aditya Bakti, 2002. 